\title{
Why it is often underestimated: Historical Study of Ammonia Gas Exposure Impacts towards Human Health
}

\author{
Diana Mutia Pratiwi ${ }^{1}$, Roekmijati Widaningroem Soemantodjo ${ }^{2,3},{ }^{*}$, Suyud Warno Utomo ${ }^{2,4}$ \\ ${ }^{1}$ Post-graduated Student, School of Environmental Science Indonesia University, Central Jakarta, Indonesia \\ ${ }^{2}$ Lecturer, School of Environmental Science Indonesia University, Central Jakarta, Indonesia \\ ${ }^{3}$ Lecturer, Chemical Engineering Department Indonesia University, Depok, Indonesia \\ ${ }^{4}$ Lecturer, Public Health Department Indonesia University, Depok, Indonesia
}

\begin{abstract}
Ammonia is one of the major pollutants in the air that easily recognized with its pungent odor, and harmful when it exposed to the human. Exposure to the released ammonia gas potentially froze all the contacted tissue, and irritations to the skin, eyes, respiratory tract, and lungs. However, due to the lack of scientific belief of carcinogenic issues for human health, exposure to the ammonia often underestimated. This study will focus on analyzing the possibility of long-term impacts towards human based on the related case of accidental or non-accidental exposure of ammonia, from the causative factors, the concentration level of gas exposure, and its impact. This study uses a narrative review based on the record of cases, and questionnaire to the workers at urea fertilizer company X. From the study of the previous similar cases, it can be inferred that short-term exposure to ammonia is proven to irritate and burns to the moisture tissue and respiratory system that able to recover with immediate treatment. Long-term exposure of ammonia did not cause a specific carcinogenic disease, but in some cases can cause a permanent burn injury, unusual habit in breathe, and in special case can cause a brain related disease.
\end{abstract}

Keywords: Ammonia, Gas Exposure, Air Quality, Human Health

\section{Introduction}

The air quality in a particular area has strongly influenced the continuation of various organism activities that lives inside it [1]. The presence of air pollutants in multiple forms (i.e., gases, particulates, and volatile compounds) can change the chemical composition in the atmosphere, potentially causing harm to the environment, particularly the living organism [2].

Air that exposed with accumulated pollutants, whether in a short or long term, potentially would impact the buildings, plants and animals, including human [3]. In the case of humans, there are three ways of air pollutants can enter the human body, which are inhalation (through the respiratory system), ingestion (gastrointestinal intact), and penetration of the skin pores [4]. There was a red thread between the quality of life and the air quality in an area, where poor air quality will cause several health problems related to respiratory disease that affects toddlers and children [5,6].

Ammonia $\left(\mathrm{NH}_{3}\right)$ is a chemical compound with boiling temperature at $-33,5{ }^{\circ} \mathrm{C}$; in a form of gas at atmospheric pressure with the characteristic of strong fume, easily dispersed (due to its light molecular weight), irritant, flammable, and high level of toxicity [7]. Ammonia commonly used in chemical industries such as fertilizer, refrigerant, explosive, as it is used as a raw material, catalyst, and reagents in many chemical processes [8]. About $85 \%$ of ammonia used as the main feed for manufacturing urea fertilizer, while another $15 \%$ used in the polymer and explosives, as a refrigerant in the heat exchanger and reducing agents in control of NOx emissions [7].

Rapid Human activities particularly industries that use fossil fuel material as the basis, has emerging several problems that related to resilience, environment, and also public health $[9,10]$. Therefore, the visions of Lowcarbon society pointed to the principle of reducing the carbon dioxide and anthropogenic greenhouse gas emission that cause harm towards the people and environment [11,12]. Ammonia also one of the major pollutants for its major role in forming secondary inorganic compound, leading to poor air quality that raise various issues on environment [13]. Gas phase Ammonia

\footnotetext{
*Corresponding author: roemws@ che.ui.ac.id
} 
also potentially causing soil and water acidification and eutrophication when it repositioned on their surface, leading to diversity loss [14]. Ammonia gas release even in the low level of concentration, able to cause harmful issue for human and ecosystems [15]. Ammonia can be hazardous when it is contacted in the tissues in living organisms that have moisture [16]. When approached with humans, ammonia gas will react with water on the surface layer in the eyes, skin, and respiratory tract to form a caustic compound ammonium hydroxide [17], causing burn sensation or irritation to the area [18].

Certain cases regarding the exposure of ammonia mainly due to the occupational accidents at the industry, related to various symptoms associated with respiratory systems, including some cases of lung inflammation due to deliberate or accidental exposure to the chemicals [19]. However, due to no scientific argument that long-term exposure of low level of ammonia will potentially cause a specific carcinogenic disease, as well as the different measurement methods of ammonia concentration, making the dangers of ammonia exposure tend to be underestimated $[13,20]$.

This paper objective is to analyse long-term impacts that potentially caused by periodical exposure of ammonia gas towards human health, particularly regarding the accidental or non-accidental cases of ammonia gas exposure towards the workers in the related industries, in order to raise awareness to the people about the dangers of excessive ammonia gas in the air besides a major contributors to forming one of the greenhouse gas emissions.

\section{Methods}

This paper presents a case study of urea fertilizer industry X in South Sumatra, Indonesia. Questionnaires to the workers in ammonia and urea plant along with the records of accidental cases related to ammonia exposure from 2015-2018 are gathered and compared to the related literature (i.e., articles or journals). Narrative review analysis then used to deliver the analysis of the impacts towards the human health both in the short and long terms of exposure.

\section{Result and Discussion}

The symptoms due to the ammonia exposure depend on the path of exposure, dose, and duration of exposure. There are some cases of ammonia gas exposure impacts towards human, such as:

a. In June 1983, worker A (male, 30 years old) was exposed to the high concentrations of anhydrous ammonia due to the leakage of ammonia refrigeration system for 15 minutes in a chamber beside his working room as an engine operator [21]. A was experiencing a burning sensation in the eyes, respiratory tract, and skin, cough, hard to breathe, along with the swelling in the eye membrane and throat. After being admitted to the hospital, the patient has difficulties to take long breathing and unable to do heavy sports activities.

b. In June 1987, worker B (Male, 27 years old) was exposed to anhydrous ammonia gas due to the leakage of the refrigeration system at the ice maker factory. Other workers accidentally opened the drainage pipe so the gas spreads in the room with inadequate ventilation. Worker B unaware of the leakage until there was a pungent odor and he spends $1.5-2$ minutes to get out of the room [21]. Worker B was experiencing difficulties in breathing, irritation in the eyes, nose, and throat, and burning sensation in the skin. After hospitalization, worker B get asthma and defect in his lungs.

c. In 2011, a worker (male, 45 years old) was admitted to the hospital for accidental exposure of ammonia gas due to the pipe leakage in the ammonia storage tank. The patients managed to escaped but suffered severe irritation and burning sensation in the eyes and throat, as well as breathing difficulties. At the ER, the patient in a state of barely breathing, having problems to open his eyes and talking [15]. The first aid treatment done is decontamination by removing the entire shirt, flowing normal saline to the eyes, after that the patient was given glycopyrrolate to reduce the water content in the body, so the ammonia no longer absorbs the water to turn into caustic compounds that irritate body [15].

The urea manufacturing process using ammonia as one of the raw feed usually takes place in closed conditions, where ammonia is stored and transported in the form of pressurized liquid [22]. Ammonia easily changes its phase when it is contacted to the atmosphere or the difference of temperatures; in any case of problem occurs, ammonia will be released from the vessel and dispersed within the air [23]. Generally, the accidental ammonia exposure caused by the leakage in the pump and valve, also ammonia storage popping due to the exceeding pressure inside the storage, automatically turning the valve open to release some of the ammonia gas into the air to keep the pressure. This sudden release of ammonia gas tend to occur in certain areas, so accidental exposure will cause eye irritation and respiratory difficulties. This disturbance categorized as first aid case which can be handled by using a gas mask, or a towel soaks with water. As for the case of ammonia exposure classified as medical treatment injury usually due to the accidental liquid ammonia splashing or sudden exposure to the high concentration of ammonia gas. There are some cases of medical treatment injury at factory X from 2015 to 2018 as shown in Table 1. 
Table 1. Accidental Cases of Ammonia Gas Exposure in the Urea Fertilizer Industry X year 2015 - 2018

\begin{tabular}{|c|c|c|c|}
\hline Year & $\begin{array}{l}\text { Number } \\
\text { of Cases }\end{array}$ & Case Description & Impacts \\
\hline \multirow[t]{2}{*}{2015} & \multirow[t]{2}{*}{2} & $\begin{array}{l}\text { a. workers in urea unit, was sprayed to the } \\
\text { liquid ammonia on the face when draining } \\
\text { the valve due to the leakage in the ammonia } \\
\text { line. }\end{array}$ & $\begin{array}{l}\text { a. Suffered the pain in the outer eyelid, } \\
\text { difficulties in breathing, and hospitalized } \\
\text { for two days. }\end{array}$ \\
\hline & & $\begin{array}{l}\text { b. welder, when checking for the welding } \\
\text { result in ammonia pipeline FA (105) that } \\
\text { repaired due to the corrosion, the plat box } \\
\text { on the pipe cannot withstand the pressure of } \\
\text { ammonia rate, causing the burst of ammonia } \\
\text { that affects the welder. }\end{array}$ & $\begin{array}{l}\text { b. Suffered burns to neck and thighs, } \\
\text { difficulties in breathing, and was } \\
\text { hospitalized more than two days. }\end{array}$ \\
\hline 2016 & 1 & $\begin{array}{l}\text { Workers in urea unit, exposed to the high } \\
\text { concentration of ammonia on the face due to the } \\
\text { leakage of one of the valves in the urea plant. }\end{array}$ & $\begin{array}{l}\text { Eyes were swelling, breathing difficulties, } \\
\text { minor burns }(10 \%) \text { on left cheek and arm. Was } \\
\text { hospitalized approximately for two days. } \\
\text { Suffered skin discoloration and needed recovery } \\
\text { for more than } 1 \text { month. }\end{array}$ \\
\hline 2018 & 1 & $\begin{array}{l}\text { Due to the miscommunication between the } \\
\text { ammonia control room and people in the port, } \\
\text { causing an imperfect treatment of the hose. At } \\
\text { the time of second ammonia loading, remaining } \\
\text { liquid ammonia in the hose was spilled and } \\
\text { affected } 2 \text { operators and the ship employee } \\
\text { whom at that time was loading the urea } \\
\text { fertilizer. }\end{array}$ & $\begin{array}{l}\text { Breathing difficulties, one of the workers } \\
\text { fainted. While the ship worker suffered a } \\
\text { fracture due to the panic attack and attempted to } \\
\text { escape from the exposure by plunge into the } \\
\text { river. }\end{array}$ \\
\hline
\end{tabular}

(source: Health and Safety Departement at fertilizer factory X, 2018)

Based on some cases above, it can be concluded that the symptoms caused by ammonia exposure depend on the path of exposure, dose, and also the duration of the exposure. Irritant symptoms after ammonia exposure generally occur at the concentration of 20-30 ppm for 1015 minutes to unaccustomed (unadaptable) individuals [24-26]. However, several studies have demonstrated that severe irritation of the eyes and respiratory tract occur at exposure to $50 \mathrm{ppm}$ or above [26]. In Verberk's (1977) study on volunteers with exposure to ammonia gas at 50 ppm for 1.5 hours showed symptoms of irritation on the eyes, nose, throat, and also impulsive coughing [24]. A similar study by Ballal et al. (1998) with male workers in two fertilizer industries, showed that workers in fertilizer factory 1 with average concentration of released ammonia were between $3-184 \mathrm{ppm}$ had a high risk of respiratory disease and asthma compared to the fertilizer factory 2 with average concentration about 0.03 - 10 ppm (below $25 \mathrm{ppm}$ ) [27]. Based on the literature studies, similar symptoms was proven based on field observation at fertilizer factory $\mathrm{X}$ describe below.

On June $13^{\text {th }}, 2018$, a high concentration of ammonia released from the vent stack in the recovery section Urea Plant 1 due to clogging in High-Pressure Decomposer (HPD). This made the carbamate solution did not perfectly decompose, causing overcarried liquid to the High-Pressure Absorber (HPA) from the design capacity. Due to the inefficiency of the decomposing and absorbing process, a high concentration of ammonia was released and carried by wind to the Fire Station and Hygiene Department Office located in the southwest of the plant. 3 people in the office are not familiar with the ammonia exposure, consist of 2 high school students, D and E (Female, 16- 17 years old) that currently in internship and 1 university student, F (Female, 26 years old) who was doing her research. D and $\mathrm{E}$ wore a mask while $\mathrm{F}$ did not have any protection (she only use a reading glasses). When the exposure occurred, based on the measurement using Drager, it was known that the concentration of ammonia gas trapped in the room reached $20 \mathrm{ppm}$, while outside the room reached $90 \mathrm{ppm}$. In the first 15 minutes, F suffered difficulties in breathing and burning sensation from the nasal cavity to the lungs. While D and E (who used a cloth mask that added with a tissue soaked with water) suffered difficulties in breathing and burn sensation in the eyes 30 minutes after. In 40 minutes (of exposure), D and $\mathrm{E}$ were sent home because one of them (who had a history of asthma) relapsed. F, in the other hand, withstand to continue to stay in the office for the next two hours while suffered burn sensation, a bitter taste in the tip of the tongue, urge to cough, and nausea. F was tried to voluntarily stand outside the office (where the ammonia concentration reaches $90 \mathrm{ppm}$ ) without using any protection, but could not withstand longer than 5 minutes due to severe irritations in the eyes, and inability to breath. After three hours of exposure, $\mathrm{F}$ was sent home due to the unfavorable office condition. After reaching the area free from exposure, $\mathrm{F}$ needs 5 minutes to regain the

\footnotetext{
*Corresponding author: roemws@che.ui.ac.id
} 
irritation in her eyes, 10 - 15 minutes to breath normally in the open space (fresh air), and 3 hours of full rest to relieve the feeling of nausea and bitterness on the tongue. The next morning (approximately 18 hours after exposure), $F$ suffered irritation of the nasal mucous membrane and excessive mucus for almost half an hour. While some symptoms occur to three people that unfamiliar with such condition, the workers (male) of the office in the same situation could withstand the exposure by using cloth mask or a hand towel soaked with water for half of the day. Based on the questionnaire, most of the worker began to adapt to the ammonia exposure condition in their office. About $94 \%$ of the worker took $3-8$ months to adapt to the working environment exposed to ammonia gas, while $6 \%$ took more than 1 year to began to adapt in the same situation. The symptoms experienced by most workers (before they are adapted) were similar to those described above depending on the concentration of the exposed gas.

Almost all of the respondents stated that they only suffered short-term impacts of ammonia gas exposure. Although the study conducted by Zala et al (2012) about health condition of 1221 workers at Urea Fertilizer Industry in India within 10 years stated that about $68.22 \%$ workers that exposed to ammonia gas at work had a bigger risk of respiratory disease (eosinophilia) 1.55 times than workers that not exposed to ammonia [28], 94\% of the workers in plant $\mathrm{X}$ did not shown any abnormalities that related to respiratory disease. The rest of the worker $(6 \%)$ only suffer burn scars after splashed with liquid or vapor ammonia and about $(25 \%)$ of the workers have a different habit of breathing deeper than normal people. But, one of the respondents stated that about $1-2 \%$ of retired workers that previously work at urea unit experiencing brain diseased that potentially caused by ammonia exposure. This opinion is similar to the study of Bosoi and Rose (2008), that accumulated concentration of ammonia in human blood potentially cause hyperammonemia,that may lead to a related brain dysfunction such as memory disturbance, sleep-wake disorder, edema, convultions, spinocerebellar degeneration, and in the worst case can cause comma [29]. Ott and Vilstrup (2013) also stated that hyperammonemia conditions, although the mechanism is still questionable, would lead to the cerebral complication that resulted by liver failure (i.e. hepatic encephalopathy) and also cerebral edema [30].

\section{Conclusion}

From the study above, it can be inferred that ammonia exposure occurs due to the unforeseen problems, mainly equipment malfunctions in the plant. Various symptoms after the exposure occur depends on two points, which are concentration level of gas and the duration. In the case of urea fertilizer industry $\mathrm{X}$, ammonia exposure will cause discomfort in the form of eye irritation, burning sensation from the nasal cavity up to the respiratory tract, nausea, and in the worst case can cause asthma and fainting. However, the impact caused by ammonia exposure only in short-term (temporary), based from the questionnaire with urea and ammonia unit workers as the respondents, about $94 \%$ stated that they did not suffer any disease that related or caused by periodic exposure to ammonia. Some workers suffered burn scars due to exposure by the liquid or vapor ammonia, a habit of breathing deeper than normal people, and about 1-2\% of the retired workers who suffered brain-related diseases (i.e., impaired memory and shortened attention span). However, the possibility of these long-term impacts might occur due to other factors (an uncertainty that these problems only occurs due to periodic exposure to ammonia), and also the ability of the workers to be adapted to work in such condition (exposed to ammonia), the impacts of ammonia exposure tend to be underestimated. Therefore, further research related to brain-disease caused by periodical exposure of ammonia particularly to the retired urea industry workers.

\section{References}

1. W. Laminack, C.Baker, J.L. Gole. Air Qual Atmos Health 9, 231 (2014).

2. R.Rai, M. Rajput, M.Agrawal, S.B.Agrawal. Journal of Scientific Research Banaras Hindu University $\mathbf{5 5}$ 77 (2011).

3. D.F. Paulsen, R.B. Denhardt. Pollution and Public Policy: A Book of Readings (Dodd Mead \& Company, USA, 1973).

4. S.E. Anderson, B.J. Meade. Environmental Health Insight 8, 51 (2014).

5. M. Darcin. (2013). Environ Sci Pollut Res 21, 1954 (2014).

6. C.A. Pope III, R.T. Burnett, M.J. Thun, E.Calle, D. Krewski, K.Ito, G.D. Thurston. J. Am. Med. Assoc. 287, 1132 (2008).

7. J. Brightling. Johnson Matthey Technol. Rev. 62, 32 (2018)

8. N. Brautbar. Toxicology and Industrial 14, 891 (1998).

9. Wachidiyah, S.W.Utomo. Asian Journal of Applied Sciences 4, 492 (2016).

10. M.F.Muhrom, R.R. Nitibaskara, H.Herdiansyah, R.Sari. IOP Conferences Series: Earth and Environmental Science 88, 1 (2017).

11. S.Peake, What is a Low-carbon society? In H.Herring, Living in a Low-carbon society in 2050. (Palgrave Macmillan, London, 2012).

12. Nuryadin, R.R.Nitibaskara, H.Herdiansyah, R.Sari. IOP Conferences Series: Earth and Environmental Science 88, 1 (2017).

13. Y.Wu., B.Gu, J.W. Erisman, S.Reis, Y.Fang, X.Lu, X. Zhang. Environmental Pollution 218, 86 (2016).

14. H.Wang, D. Zhang, Y. Zhang, L. Zhai, B.Yin, F.Zhou, Y. Geng, J. Pan, J.Luo, B.Gu, H.Liu. Environmental Pollution 235, 482 (2018).

15. J. Aubrecht, L. Kalvoda. Journal of Sensors 2016, 1 (2016).

16. Bhalla, S. Mahi, N. Sharma, S. Singh. (2011). J.Emerg. Trauma Shock 4, 140 (2011). 
17. C.E. White, M.S. Park, E.M. Renz, S.H. Kim, A.E. Ritenour, S.E. Wolf, L.C. Cancio. Journal of Burn Care \& Research 28, 922 (2007).

18. R.B. Swotinsky, K.H Chase. American Journal of Industrial Medicine 17, 515 (1990).

19. N. Brautbar, M.P. Wu, E.D. Richter. Journal of Environmental Medicine 58, 592 (2003).

20. C.L. Heald, J.L. Collet Jr., T. Lee, K.B. Benedict, F.M. Schwandner, L.Clarisse, D.R. Hurtmans, M. Van Damme, C. Clerbaux, P.-F. Coheur, S.Philip, R.V. Martin, H.O.T. Pye. Atmos. Chem. Phys. 12, 21 (2012)

21. R.E. De la Hoz, D.P. Schlueter, W.N. Rom. American Journal of Industrial Medicine 29, 209 (1996).

22. C.E. Armshel, M.H. Fealk, B.J. Philips, D.M. Caruso. Burns 26, 493 (2000).

23. J. Labovsky, L. Jelemensky, L. Process Safety and Environmental Protection 88, 243 (2010).
24. M.M. Verberk. Int Arch Occup Environ Health 39, 73 (1977)

25. S.I. Sekizawa, H. Tsubone. Respir. Physiol. 96, 37 (1994).

26. M.J. Fedoruk, R. Bronstein, B.D. Kerger. J. Expo. Anal. Environ. Epidemiol. 15, 534 (2005).

27. S.G.Ballal, B.A. Ali, A.A. Albar, H.O. Ahmed, A.Y. Al-Hasan. Int. J.Tuberc.Lung.Dis. 2, 330 (1998).

28. N. Zala, A. Kavishvar. Indian J Occup Environ Med 16, 142 (2012).

29. C.R. Bosoi, C.F. Rose. Metab. Brain. Dis. 24, 95 (2009).

30. P.Ott, H. Vilstrup. Metab. Brain. Dis. 29, 901 (2014). 